\title{
KUALITAS PELAYANAN DALAM PEMBUATAN KARTU KELUARGA DI KECAMATAN MEKARMUKTI KABUPATEN GARUT
}

\author{
Oleh \\ Heldi \\ Universitas Islam Negeri (UIN) Sunan Gunung Djati Bandung \\ Email: heldi@uinsgd.ac.id
}

\begin{abstract}
Quality Service Of Making Family Card In Mekarmukti Of Garut. Problem in this research is Mekarmukti employee which not maximal in serving the community especially in making family card as mandated in the constitutional number 25 of 2009 about public service. There are residents which does not care about the importance of having family card, retardation of employee in making family card, less of facilitation in Mekarmukti make the process of making family card was delayed. Research method which used in this research is descriptive qualitative which used interview, study documentation, and obsevation as the technique of collecting data. Data which used in this research is primary data and secondary data with Mekarmukti goverment such as the chief of village, society which chosen by technique of determination informant purposive sampling as the subject of research. Result of this reseach is: the quality service in Mekarmukti already appropriate to the procedure but the facilities in Mekarmukti is the reason why the service is delayed.
\end{abstract}

Keywords: Quality Service \& Family Card

\section{PENDAHULUAN}

Pelayanan terhadap masyarakat menjadi hal yang sangat penting dan merupakan sebuah tuntutan bagi pegawai pemerintahan untuk memenuhi kebutuhan masyarakat dalam melakukan pelayanan. Sebagaimana diamanatkan Undang-Undang Nomor 25 tahun 2009 tentang pelayanan publik, bahwa setiap penyelenggara pelayanan publik, baik yang memberikan pelayanan kepada masyarakat secara langsung maupun tidak langsung wajib menyusun, menetapkan dan menerapkan standar pelayanan untuk setiap jenis pelayanan sebagai tolok ukur dalam penyelenggaraan pelayanan di lingkungan masing-masing.

Menurut bapak Icang Hadiat selaku Kepala Seksi Pemerintahan Kecamatan Mekarmukti, Ketidak sesuaian antara target dengan hasil yang peroleh dalam pembuatan Kartu keluarga di sebabkan oleh keterlambatan pada saat pembuatan Kartu Keluarga masyarakat harus menunggu 2-3 minggu bahkan bisa sampai berbulan-bulan, hal tersebut tidak di tangani secara cepat meskipun masyarakat udah bolak-balik mendatangi kantor kecamatan dan terkadang ada warga yang datang kerumah untuk menanyakan hal terkait pembuatan Kartu keluarga tersebut.

Minimnya pengetahuan ilmu teknologi hal ini di sadari juga oleh bapak Heri selaku kepala bagian pelayanan bahwa kebanyakan yang bekerja adalah lulusan SMA sehingga pegawai tidak terlalu faham dalam penggunaan jaringan internet dan komputer, dan komputer hanya di gunakan untuk sebatas mengetik saja. Selanjutnya kurangnya fasilitas yang ada di bidang pelayanan, sehingga hal tersebut dapat menghambat berjalannya kegiatan yang ada di bidang pelayanan.

\section{LANDASAN TEORI}

Administrasi publik menurut Pasolong (2013: 8) adalah kerjasama yang dilakukan oleh sekelompok orang atau lembaga dalam melaksanakan tugas-tugas pemerintahan dalam memenuhi kebutuhan publik secara efisien dan efektif.

Kualitas Pelayanan 
Menurut Sampara (1999:14)

"Kualitas pelayanan adalah pelayanan yang di berikan kepada pelanggan sesuai dengan standar telah di bakukan sebagai pedoman dalam memberikan layanan. Standar pelayanan adalah ukuran yang telah di tentukan sebagai suatu pembakuan pelayanan yang baik."

\section{Dimensi Kualitas Pelayanan}

Menurut Zeithaml dan Berry yang di kutip dalam Tjiptono \& Chandra (2016:137) kualitas pelayanan dapat di ukur dari 5 dimensi yaitu:

1. Untuk dimensi Tangibel (berwujud) yaitu berkenaan dengan daya tarik fasilitas fisik, perlengkapan, dan material yang di gunakan perusahaan, serta penampilan karyawan.

2. Untuk mensi Reliability (kehandalan), berkaitan dengan kemampuan perusahaan atau lembaga untuk memberikan pelayanan yang akurat sejak pertama kali tanpa membuat kesalahan apapun dan menyampaikan jasanya dengan tepat waktu.

3. Untuk dimensi resvonsiviness (respon/tanggapan), berkenaan dengan kesediaan dan kemampuan para pegawai untuk membantu para pelanggan dan merespon permintaan mereka secara tepat, serta menginformasikan kapan saja akan diberikan dan kemudian memberikan jasa secara cepat.

4. Untuk dimensi assurance (jaminan), yakni perilaku para pegawai mampu menumbuhkan kepercayaan pelanggan terhadap perusahaan dan perusahaan bisamenciptakan rasa aman dan nyaman bagi pelanggannya yang di layaninya.

5. Untuk dimensi Empathy (empati), berarti bahwa perusahaan memahami masalah para pelanggannya dan bertindak demi kepentingan pelanggan serta memberikan perhatian personal kepada para pelanggan dan memiliki jam operasional yang nyaman,

\section{METODE PENELITIAN}

Penelitian Kualitas Pelayanan Dalam

Pembuatan Kartu Keluarga (KK) Di Kecamatan Mekarmukti Kabupaten Garut menggunakan metode kualitatif dengan pendekatan deskriptif.

Menurut David Williams (1995) yang di kutip oleh Maleong 2011:5). Menulis bahwa penelitian kualitatif adalah pengumpulan data pada suatu latar alamiah, dengan menggunakan metode alamiah, dan di lakukan oleh orang atau peneliti yang tertarik secara alamiah.

\section{Teknik Pengumpulan Data}

Pengumpulan data dapat di defiisikan sebagai satu proses mendapatkan teknik pengumpulan data yang tepat di gunakan dan meyusu istrumen yang digunakan untuk mengumpulkan data (Ulber Silalahi, 2012:280). Dalam penelitia ini pengumpulan data dilakuka dengan menggunakan beberapa teknik, yaitu :

\section{Observasi}

Observasi adalah pengambilan data dengan menggunakan mata tanpa ada pertolongan alat standar lain untuk keperluan tersebut. Dalam kegiatan sehari-hari, kita selalu menggunakan mata untuk mengamati sesuatu. Observasi ini di gunakan untuk peelitian yang telah di rencanakan secara sistematik dalam jalannya proses pelaksanaan pelayanan publik di Kecamatan Mekarmukti Kabupaten Garut.

Tujuan peggunaan metode ini untuk mencatat hal-hal, perilaku, perkembangan, dan dalam berjalannya proses pelaksanaan pelayanan publik di kantor Kecamatan Mekarmukti Kabupate Garut, sewaktu kejadian tersebut berlaku sehingga tidak menggantungkan data dari ingatan seseorang. Observasi juga dapat memperoleh data dari subjek baik yang tidak dapat berkomunikasi secara verbal atau yang tak mau berkomuikasi secara verbal.

\section{Wawancara}

Wawancara adalah metode yang di gunakan untuk mengumpulkan data atau keterangan lisan dari seseorang yang di sebut responden melalui suatu percakapan yang sistematis dan terorganisasi (Ulber Silalahi, 2012:312).

Tujuan penulis menggunakan metode ini, untuk memperoleh data secara jelas dan kongkret tentang pelaksanaan pelayanan publik di Kantor Kecamatan Mekarmukti Kabupaten Garut.

3. Dokumentasi 
Dokumentasi adalah setiap bahan tertulis baik berupa karagan, memo, pengumuman, instruksi, majalah, buletin, pernyataan, aturan suatu lembaga masyarakat, dan berita yang di siarkan kepada media massa. Dokumentasi merupakan cara pengumpulan data melalui peninggalan tulisan terutama berupa arsip-arsip dan termasuk juga bukubuku mengenai pendapat, dalil yang berhubungan dengan masalah penyelidikan. Sumber dokumentasi yang di gunakan dalam penelitian ini di antaranya data-data yang di miliki pemerintah kecamatan.

\section{Teknik Analisi Data}

Teknik analisis data yang di gunakan dalam penelitian ini adalah dengan menggunakan model analisis seperti yang telah di berikan oleh miles dan Huberman dalam (Ulber, 2012:339), yaitu:

\section{Reduksi Data}

Data yang di peroleh di lapangan jumlahnya cukup banyak, untuk itu perlu di catat secara teliti dan rinci. Reduksi data merupakan suatu bentuk analisis yang menajamkan, menggolongkan, mengarahkan, membuang yang tidak perlu, dan mengorganisasis data sedemikian rupa hingga kesimpulan-kesimpulan finalnya dapat di tarik dan diverifikasi. Jadi dalam penelitian kualitatif , "reduksi data"tidak perlu mengartikannya sebagai kuantifikasi.

2. Penyajian Data

Setelah di reduksi, maka langkah berikutnya adalah penyajian data, penyajian data dalam penelitian kualitatif dewasa ini juga dapat dilakukan dalam berbagai jenis matriks, gerafik, jaringan, dan bagan. Semuanya di rancang guna menggabungkan informasi yag tersusun dalam suatu betuk yang padu da mudah di raih. Dengan demikian, seorang penganalisis dapat melihat apa yang sedang terjadi dan menentukan apakah menarik kesimpulan yang benar ataukah terus melangkah melakukan analisis yang menurut saran yang di kiaskan oleh penyajinya sebagai suatu uang mungkin berguna. Jadi, penyajian data merupakan bagian dari analisis. Merancang deretan kolom-kolom sebuah matriks untuk data kualitatif dan memutuskan jenis dan bentuk data harus di masukan kedalam kotak-kotak matriks merupakan kegiatan analisis.

3. Penarikan kesimpulan da verifikasi

Langkah ketiga penarikan kesimpulan dan verifikasi. Ketika kegiatan pengumpulan data dilakukan, seorang menganalisis kualitatif mulai mencari arti benda-benda, mecatat keteraturan, pola-pola, penjelasan konfigurasikonfigurasi yang mungkin, alur sebab akibat, dan proposisi. Mula-mula kesimpulan belum jelas, tetapi kemudian kian meningkat menjadi lebih terperinci. Kesimpulan-kesimpulan "final" mugkin tidak mucul sampai pengumpulan data berakhir, bergantung pada besarya kumpulan-kumpulan catatan lapangan, pengkodeannya, penyimpanan, dan metode pencarian ulang yang di gunakan, kecakapan peeliti, dan tuntutan penberian dana, tetapi sering kali kesimpulan itu telah di rumuskan sebelumnya sejak awal, sekalipun seorang peneliti menyatakan telah melanjutkannya "secara induktif".

Kesimpulan atau kesimpulankesimpulan di verifikasi selama peelitian berlangsung. Verifikasi itu mungkin sesingkat pemikira kembali yag melintas dalam pikiran menganalisis selama dia menulis, suatu tinjauan ulang pada catatan-catatan

lapangan, atau mungkin begitu saksama dengan peninjauan kembali untuk mengembangkan "kesepakatan intersubjektif".

\section{HASIL DAN PEMBAHASAN}

Penelitian Kualitas Pelayanan Di Kabupaten Garut dilaksanakan di Kecamatan Mekarmukti. Kecamatan ini merupakan pemekaran dari Kecamatan Bungbulang yang diresmikan pada tanggal 20 Desember 2002 dan terdiri dari 5 Desa dan telah mengalami pergantian Camat sebanyak 8 kali dan memiliki pegawai sebanyak 22 orang. Kemudian penduduk yang ada di kecamatan Mekarmukti pada tahun 2017 yakni sebanyak 17383 orang.

Yang wajib memiliki Kartu Keluarga 10838 orang, namun dengan hambatan yang dipaparkan oleh informan kepada peneliti seperti kurangnya fasilitas yang ada di kecamatan Mekarmukti meliputi alat pencetak 
dan blanko yang sering kali kekurangan dan masih membutuhkan penambahan fasilitas dari pemerintah pusat, warga setempat masih harus pergi ke pusat atau ke Capil untuk pembuatan Kartu Keluarga kemudian kurangnya ilmu pengetahuan dan teknologi pegawai yang disebabkan oleh banyaknya pegawai lulusan SMA dan kurangnya Pegawai Negeri Sipil (PNS) dan masih kurang pembekalan mengenai pengunaan elektronik.

Selanjutnya kecamatan Mekar-mukti memiliki standar pelayanan yang jelas yang merupakan sebuah pedoman untuk pegawai dalam melayani masyarakat, namun seringkali sebuah rencana yang dibuat oleh kepala seksi pelayanan tidak sesuai dengan rencana yang telah dirancang sebelumnya sehingga timbullah masalah, yang salah satunya yaitu banyak Masyarakat yang belum memiliki Kartu Keluarga.

\section{PENUTUP \\ Kesimpulan}

Kesimpulan dari penelitian ini yang dilakukan dilapangan baik hasil wawancara, observasi dan dokumentasi yang dilakukan dalam upaya mengetahui bagaimana Kualitas Pelayanan Dalam Pembuatan Kartu Keluarga (KK) Di Kecamatan Mekarmukti Kabupaten Garut, dengan menggunakan 5 Dimensi diperoleh kesimpulan bahwa Kualitas pelayanan Dalam Pembuatan Kartu Keluarga (KK) Di Kecamatan Mekarmukti Kabupaten Garut antara lain sebagai berikut, Kualitas pelayanan yang di tuangkan dalam UndangUndang no. 25 tahun 2009 bertujuan untuk meningkatkan Kualitas pelayanan di Kecamatan Mekarmukti khususnya dalam pembuatan Kartu Keluarga yang memang di nilai langsung oleh masyarakat Kecamatan Mekarmukti. Adapun untuk menunjang kelancaran dalam melayani masyarakat, pemerintah kecamatan mekarmukti memberikan pelayanan yang baik terhadap masyarakat dengan cara memkolektifkan pembuatan kartu keluarga untuk di buat di pusat supaya masyakat bisa mendapatkan kartu keluarga, kemudian pegawai juga memberikan kesempatan kepada masyaakat untuk memberikan penilaian terkait bagaimana kualitas pelayanan di Kecamatan Mekarmukti. Kualitas pelayanan yang ada di kecamatan mekarmukti tergantung bagaimana pegawai dalam melaksanakan pelayanan terhadap masyarakat kemudian masyarakat menilai bagaimana kualitas pelayanan pegawai nya, kedisiplinannya, sopan santun dan kecepatan dalam melayani masyarakat, karena masyarakatlah yang akan merasakan bagaimana pelayanan yang baik di Kecamatan.

\section{DAFTAR PUSTAKA}

[1] Anggara Sahya, 2012. Ilmu administrasi negara. Bandung: CV Pustaka Setia.

[2] Buku Panduan Kecamatan Mekarmukti.

[3] Dewa Jufri,2011. Hukum Administrasi Negara Dalam Perspektif Pelayanan Publik, Universitas Haluoleo Kampus Hijau Bumi Tridharma : Unhalu Press

[4] Hardiyansyah, 2011. Kualitas Pelayanan Publik, Yogyakarta: Gava Media.

[5] Maleong, 2011. Metodologi Penelitian Kualitatif, Bandung: PT Remaja Rosdakarya.

[6] Masyhuri, 2011. Metodologi Penelitian Pendekatan Praktis Dan Aplikatif, Bandung: PT Refika Aditama.

[7] Mulyadi Deddy. 2016. Administrasi Publik Untuk Pelayanan Publik, Bandung: Alfabeta.

[8] Pasolong, Herbani. 2013, Teori Administrasi Publik. Bandung: Alfabeta.

[9] Sedarmayanti, 2017. Reformasi Administrasi Publik, Reformasi Birokrasi, dan Kepemimpinan Masa Depan. Bandung: PT Refika Aditama.

[10] Sueb Muhammad Ridha, 2016. Pengantar Kebijakan Publik. Yogyakarta:Calpulis

[11] Silalahi Ulber, 2012, Metode Penelitian Sosial. Bandung: PT Refika Aditama.

[12] Sugiyono,2016, Metode Penelitian Administrasi. Bandung: Alfabeta.

[13] Trisakti Fajar, 2017, Reformasi Administrasi. Bandung: Fisip Unpas Press 